\title{
Automatic Scroll Saw System Dengan Teknik Kendali Kecepatan Pulse Width Modulation (PWM) Berbasis Arduino UNO
}

\author{
Ardianto Pranata \\ Sistem Komputer,STMIK Triguna Dharma \\ Email: ardianto_pranata@yahoo.com
}

\begin{abstract}
Abstrak
Scroll Saw merupakan gergaji mesin yang dikhususkan untuk pemotongan pola-pola khusus. Biasanya digunakan untuk kerajinan tangan dengan material tipis seperti tripleks atau cangkang kelapa. Scroll saw yang memanfaatkan tenaga listrik dan motor penggerak biasanya memiliki kecepatan konstan dan tetap, sehingga tidak jarang objek yang dipotong akan rusak atau pecah terutama untuk objek yang ketebalan dianggap tipis. Oleh karena itu dibutuhkan sebuah kendali kecepatan otomatis yang dapat menyesuaikan secara otomatis berdasarkan salah satu faktor objek seperti ketebalannya. Dengan memanfaatkan arduino sebagai kendali otomatis serta teknik kendali kecepatan yakni pulse width modulation (PWM) serta sensor ultrasonic untuk mendeteksi ketebalan objek yang dipoting. Sistem diharapkan mampu menyesuakain kecepatan secara otomatis pada saat proses pemotongan berdasarkan ketebalan objek. Sehingga meminimalisir kerusakan objek yang dipotong.
\end{abstract}

Kata kunci : Scrall Saw, Arduino, Pulse Width Modulation, Ultrasonic

\begin{abstract}
Scroll Saw is a chainsaw that is specialized for cutting special patterns. Usually used for handicrafts with thin materials such as plywood or coconut shells. Scroll saw that utilizes electric power and a driving motor usually has a constant and constant speed, so it is not uncommon for the object being cut to be damaged or broken, especially for objects whose thickness is considered thin. Therefore we need an automatic speed control that can adjust automatically based on one of the object factors such as thickness. By utilizing Arduino as automatic control and speed control techniques, namely pulse width modulation (PWM) and ultrasonic sensor to detect the thickness of the object being rotated. The system is expected to be able to adjust the speed automatically during the cutting process based on the thickness of the object. So as to minimize the damage to the object being cut.
\end{abstract}

\section{Keywords : Scrall Saw, Arduino, Pulse Width Modulation, Ultrasonic}

\section{PENDAHULUAN}

Scroll saw merupakan pengembangan gergaji pola dengan mata ulir baja tipis yang bisanya digunakan dalam proses pemotongan objek dengan ketebalan tipis seperti tripleks dan cangkang kelapa, namun ada juga beberapa yang dikhususkan untuk pemotongan besi atau sejenisnya. "Gergaji merupakan alat yang menggunakan logam pemotong atau kawat dengan tepi kasar untuk memotong bahan yang lebih lunak. Tepi logam pemotong biasanya dirancang dengan bentuk bergerigi"'[1]. Jenis scrall saw manual awalnya hanya menggunakan tenaga manusia sebagai penggerak mata gergaji dimana kecepatan dan tenaga yang digunakan berdasarkan kemampuan manusia yang tidak konstan dan cenderung berubahubah. Sedangkan jenis scrall saw otomatis yang sudah menggunakan tenaga listrik, bekerja dengan kecepatan konstan dari awal pengaktifan hingga proses pemotongan selesai. Kendala yang diperoleh dari scrall saw tenaga listrik adalah ketika objek yang dipotong terlalu tipis maka kecepatan konstan dari mesin scrall saw berakibat pada rusaknya objek yang dipotong,. Sehingga obejek yang dipotong tidak dapat digunakan sesuai dengan yang semestinya. Dengan demikian dibutuhkan sebuah kendali kecepatan yang dapat mengatur penyesuaian kecepatan gergaji pola pada saat memotong objek dengan ketebalan tertentu. Salah satu yang dapat digunakan adalah teknik kendali menggunakan Pulse Width Modulation. 
Pulse Width Modulation (PWM) merupakan salah satu jenis teknik dalam sistem kendali, yakni sebuah cara manipulasi lebar sinyal yang dinyatakan dengan pulsa dalam suatu periode [2]. Sistem kendali dilakukan dengan cara mengubah perbandingan lebar pulsa positif terhadap lebar pulsa negatif ataupun sebaliknya dalam frekuensi sinyal yang tetap. PWM biasanya sering diimplementasikan pada modulasi data untuk telekomunikasi, pengendali daya atau tegangan, regulator, audio effect dan penguat aplikasi-aplikasi lainnya. Termasuk implementasinya guna mengatur kecepatan motor DC pada sistem kendali otomatis di dunia elektronika dan industri. Dalam hal ini PWM diterapkan pada motor DC sebagai penggerak Scroll Saw yang diimplementasikan pada sebuah board arduino.

Arduino sendiri merupakan boardloader mikrokontroler yang memanfaatkan chip ATMega 328. Arduino memiliki kelebihan dalam kemudahan penggunaan mikrokontroler jenis ATMega328 dimana boardloader ini sudah terintegritas untuk pemrograman berbasis bahasa $\mathrm{C}$ yang cukup sederhana. Selain itu arduino juga memiliki input output interface yang mana diantara pin nya memiliki fungsi khusus PWM[3]. Arduino sendiri menggunakan tegangan kerja 3.3 Volt hingga 5 Volt. Yang mana kondisi tersebut semakin mempermudah pengolahan dan pengaturan untuk penerapan teknik PWM.

\section{KAJIAN TEORITIS}

\section{a. Scroll Saw}

Gergaji merupakan salah satu peralatan yang sering digunakan di dunia industri khususnya mebel. Dimana fungsi awalnya adalah untuk memotong kayu yang mana proses penggunaannya masih dilakukan secara manual menggunakan tenaga manusia. Namun berkembangnya waktu penggunaan gergaji manual kini sudah berpindah menjadi gergaji mesin [4]. Dalam perkembangannya kini gergaji memiliki fungsi yang beragam selain memotong kayu, bambu, akrilik bahkan hingga besi sekaligus. Dengan kemudahan penggunaan mesin kini muncul variasi- variasi dari gergaji antara lain gergaji piringan, gergaji baja serta gergaji pola (Scroll Saw) atau sering juga disebut gergaji pita. Jika proses pemotongan secara manual membutuhkan waktu yang cukup lama dan membutuhkan banyak tenaga [5], kini dengan bantuan mesin proses pemotongan menjadi lebih singkat dan mudah.

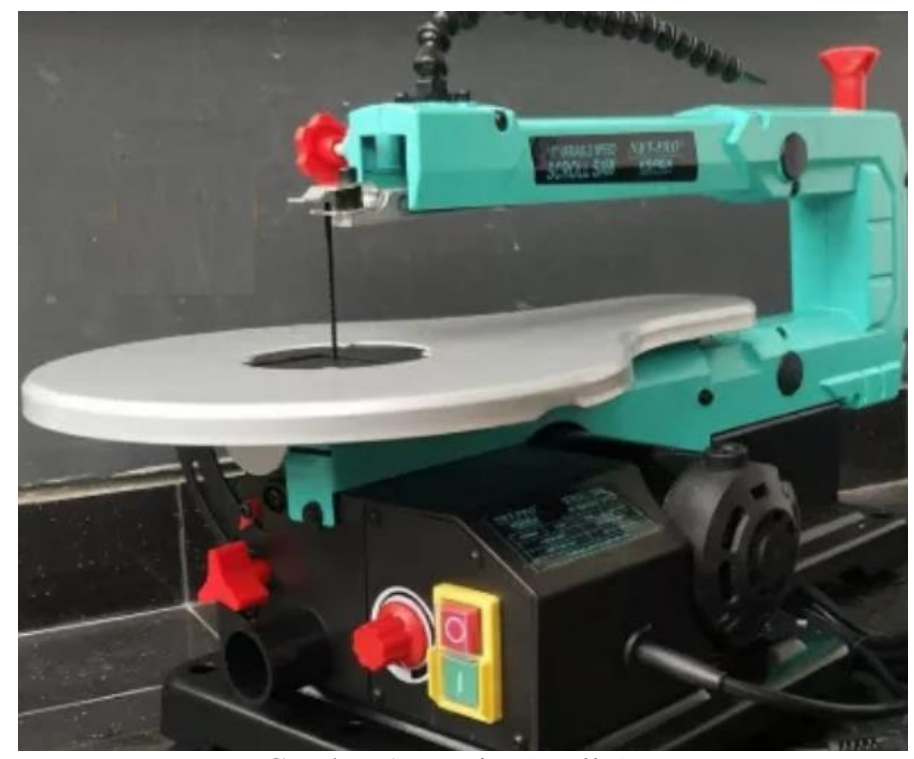

Gambar 1. Mesin Scroll Saw

\section{a. Pulse Width Modulation}

PWM merupakan sinyal analog yang memiliki amplitude dan frekuensi dasar tetap, yang mengalami perubahan hanya pada lebar pulsa dan memiliki duty cycle bervariasi antara 0\% sampai 100\%[6]. Pada dasarnya PWM biasanya digunakan untuk telekomunikasi (modulasi data), penguat (amplifier), pengatur daya dan juga sebagai regulator tegangan.

Pulse Width Modulation (PWM) adalah sebuah cara memanipulasi lebar sinyal yang dinyatakan dengan pulsa dalam suatu periode [7]. Aplikasi PWM berbasis mikrokontroler biasanya berupa pengendalian kecepatan motor DC, Motor Servo, pengaturan nyala terang LED. Pada metode digital setiap perubahan PWM dipengaruhi oleh resolusi dari PWM itusendiri. 


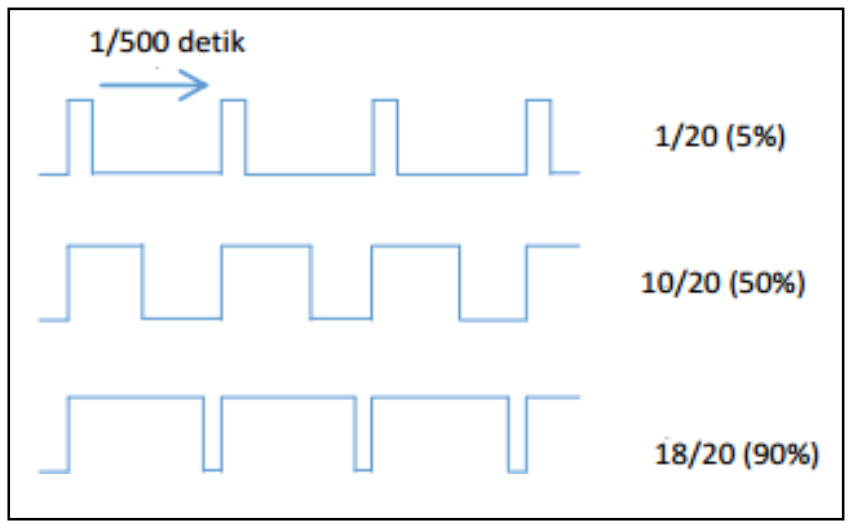

Gambar 2. Sinyal Pulsa PWM

\subsubsection{Penyakit Parasit pada Kucing}

Menurut Drh.RachmadWahyudi,M.si(Han) parasit dapat dikelompokkan mejadi 2 yaitu:

1. Ektoparasit

Ektoparasit yang sering menyerang kucing adalah pinjal (flea),dan tungau (mite),Pinjal banyak ditemukan pada kucing, hampir semua kucing yang dibiarkan hidup di luar rumah selalu ditemukan pinjal di rambutnya. Pinjal hidup di permukaan tubuh kucing, pinjal dewasa dan bertelur di kulit, menghisap darah kucing. Telur dapat jatuh ke lingkungan, sehingga pemberantasan pinjal pada kucing juga harus dipikirkan juga memberantas pinjal yang ada di lingkungan sekitar kucing.

2. Endoparasit

Endoparasit yang sering menyerang kucing adalah berbagai macam cacing, termasuk cacing gilig dan cacing pita. Cacing gilig adalah cacing berbentuk gilig dengan berbagai ukuran seperti Ancylostoma dan Toxocara yang banyak menyerang saluran pencernaan usus pada kucing, berbagai organ kucing seperti jantung, paru-paru, ginjal dan lain-lain.

\section{b. Arduino Uno}

“Arduino Uno adalah sebuah board mikrokontroler yang didasarkan pada Atmega328. Arduino UNO mempunyai 14 pin digital input/output (6 diantaranya dapat digunakan sebagai luaran PWM), 6 masukan analog, sebuah osilator $16 \mathrm{MHz}$, sebuah koneksi USB, sebuah power jack, sebuah ICSP header, dan sebuah tombol reset. Arduino UNO mampu men-support mikrokontroler, dan dapat dikoneksikan dengan komputer mengunakan kabel USB'[8]

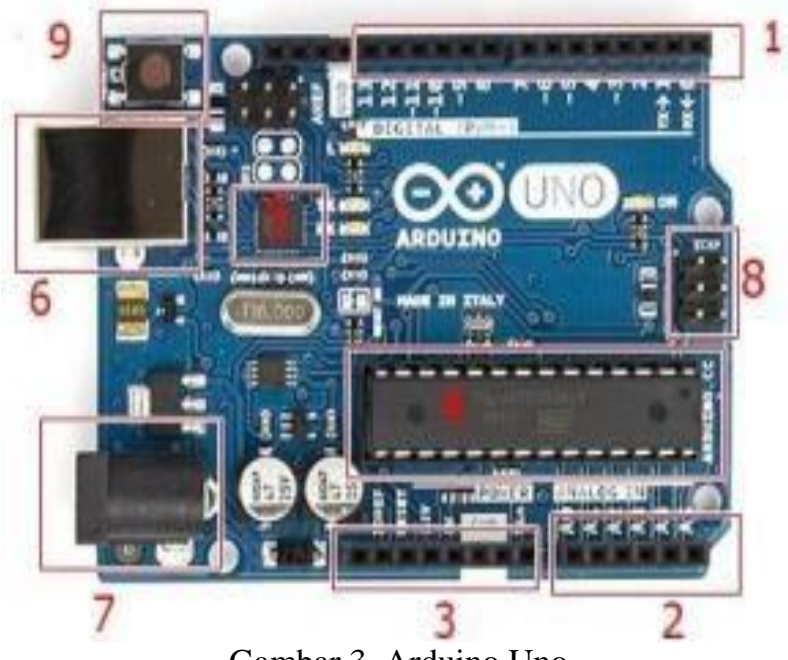

Gambar 3. Arduino Uno

1) Pin input/output digital (diberi Label 0 sampai13 ${ }^{\mathrm{ec}}$ )

Secara umum pin I/O ini adalah pin digital, yakni pin yang bekerja pada level tegangan digital (0V sampai 5V) baik untuk input atau output.namaun pada bebrapa pin output analog, yang dapat mengeluarkan tegangan analog $0 \mathrm{~V}$ sampai $5 \mathrm{~V}$, pin tersebut adalah pin 3,5,6,9,10 dan 11, selain itu untuk pin 0 dan 1 juga memiliki fungsi khusus sebagai pin komunikasiserial. 
2) Pin input analog(diberi Label „A0 sampaiA5"e).

Pin tersebut dapat menerima input tegangan analog antara $0 \mathrm{~V}$ sampai $5 \mathrm{~V}$, tegangan ini akan direpresentasikan sebagai bilangan 0 - 1023 dalam program.

3) Pin untuk sumbertegangan

Kelompok pin ini merupakan kumpulan pin yang berhubungan dengan sumber tenaga, missalnya output 5V, Output 3,3V, GND (2 pin) dan Vref (tegangan referensi untuk pembacaan ADC internal)

4) ICATMega 328

Seperti yang telah dijelaskan IC ini bertindak sebagai pusat kendali pemrosesan data.

5) ICATMega16U

IC ini diprogram untuk menangani komunikasi data dengan PC melalui port USB.

6) JackUSB

Merupakan soket USB tipe B sebagai penghubung data serial dengan PC.

7) Jack Power

Merupakan Soket untuk catu daya eksternal antara 9V samai 12V DC.

8) Port ICSP (In-Circuit SerialPrograming)

Port ini digunakan untuk memprogram arduino tanpa bootloader.

9) TombolReset

Digunakan untuk mereset papan mikrokontroller arduino untuk memulai program dari awal.

\section{c. Ultrasonic}

Sensor ultrasonik adalah sebuah sensor yang berfungsi untuk mengubah besaran fisis (bunyi) menjadi besaran listrik dan sebaliknya. Gelombang ultrasonik adalah gelombang bunyi yang mempunyai frekuensi $20.000 \mathrm{~Hz}$.[9]. Sensor ultrasonik merupakan salah satu sensor yang menghasilkan besaran analog. Aplikasi dari sensor ultrasonik diantaranya adalah untuk menentukan ketinggian air bendungan, sistem kendali robot, dan lain-lain[10].

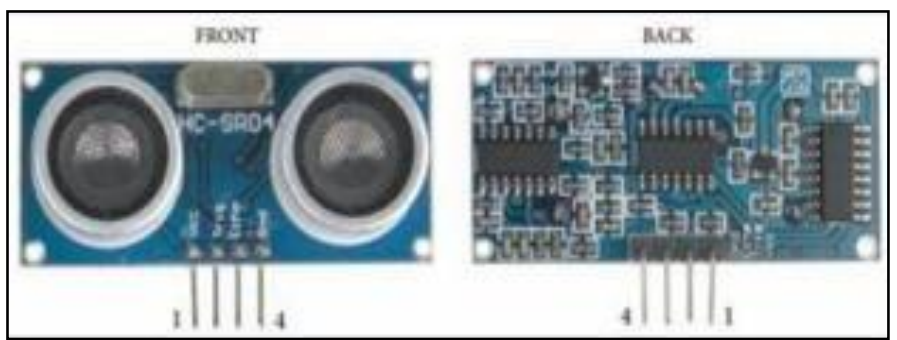

Gambar 4. Sensor Ultrasonic

\section{METODE PENELITIAN}

Metode penelitian adalah bagian dari suatu cara atau prosedur yang digunakan untuk mengumpulkan data. Metodologi penelitian merupakan cara yang digunakan untuk memperoleh data menjadi informasi yang lebih akurat sesuai permasalahan yang akan diteliti

Adapun metode-metode yang digunakan antara lain:

a. Studi Literatur

Merupakan salah satu metode yang digunakan untuk mengumpulkan data dari berbagai sumber seperti jurnal, artikel, buku dan hasil penelitian. Literature berfokus pada teoritis terkait objek penelitian, hardware dan software perancangan sistem serta pengujian. Literatur hardware terkait penggunaan arduino sebagai sistem kendali, teknik kendali PWM serta penggunaan sensor input sepertiultrasonik

b. Pengujian atau Eksperimental

Salah satu metode yang dilakukan guna membuktikan data-data yang diperoleh dari penelitianpenelitian sebelumnya untuk mendapatkan data perbandingan yang lebih akurat dan terpercaya. Pengujian dari hasil penelitian sebelumnya seperti penggunaan ultrasonik dengan Arduino Uno sebagai satu kesatuan sistem serta penerapan teknik PWM pada kendali otomatis.

c. Pengamatan Langsung

Pada metode ini dilakukan dengan pengamatan langsung terkait konsep penggunaan scroll saw (Gergaji Pola), Gergaji Pita atau sejenisnya, baik konstruksi maupun konsep penggunaan. Pengamatan 
dilakukan dibeberapa toko dan industri mable khususnya yang industri kerajinan dengan bahan dasar kayu, batok kelapa, tripleks dan sebagainya.

\section{ALGORITMA SISTEM}

Algoritma sistem merupakan perhitungan dari teknik PWM dimana, Teknik PWM yang digunakan adalah kendali level kecepatan motor dengan mengatur tegangan kerja untuk merubah nilai RPM pada motor. Motor yang menggunakan tegangan kerja 9 Volt akan direpresentasikan pada sinyal analog arduino 0-255, dimana kika direpresentasikan pada presentasi maka 0 direpresentasikan sebagai $0 \%$ dan 255 akan direpresentasikan sebagai $100 \%$. Dengan menggunakan perbandingan tersebut maka pembagian presentasi level motor dapat diatur. Adapun nilai presentasi dan hubungan terhadap nilai tegangan kerja motor diperoleh dengan perhitungan berikut;

Level PWM = Duty Cycle x Nilai Tegangan

1. Nilai Level Tegangan Kerja untuk duty cycle $0 \%$ adalah

Level $1=0 \% \mathrm{x}$ Tegangan Kerja

$$
=\frac{0}{100} \times 9=0 \text { volt }
$$

2. Nilai Level Tegangan Kerja untuk duty cycle 50\% adalah

Level $2=50 \% \times$ Tegangan Kerja

$$
=\frac{150}{100} \times 9=4.5 \text { volt }
$$

3. Nilai Level Tegangan Kerja untuk duty cycle $100 \%$ adalah

Level $3=90 \% \mathrm{x}$ Tegangan Kerja

$$
=\frac{90}{100} \times 9=8,1 \text { volt }
$$

Sedangkan representasi level PWM untuk nilai sinyal analog yang sesuai dengan masing-masing presentasi level dapat dihitung sebagai berikut;

1. Nilai Level Sinyal Analog untuk duty cycle $0 \%$ adalah

Level $1=0 \%$ x Sinyal Analog Maksimal

$$
=\frac{0}{100} \times 255=0
$$

2. Nilai Level Sinyal Analog untuk duty cycle 50\% adalah

Level $2=50 \%$ x Sinyal Analog Maksimal

$$
=\frac{50}{100} \times 255=127,5
$$

3. Nilai Level Sinyal Analog untuk duty cycle $100 \%$ adalah

Level $3=90 \% \times$ Sinyal Analog Maksimal

$$
=\frac{90}{100} \times 255=229,5
$$

Sehingga dari perhitungan di atas, maka hubungan perubahan pulsa sinyal PWM pada masing-masing Duty Cycle dapat direpresentasikan seperti pada gambar 5 di bawah ini;

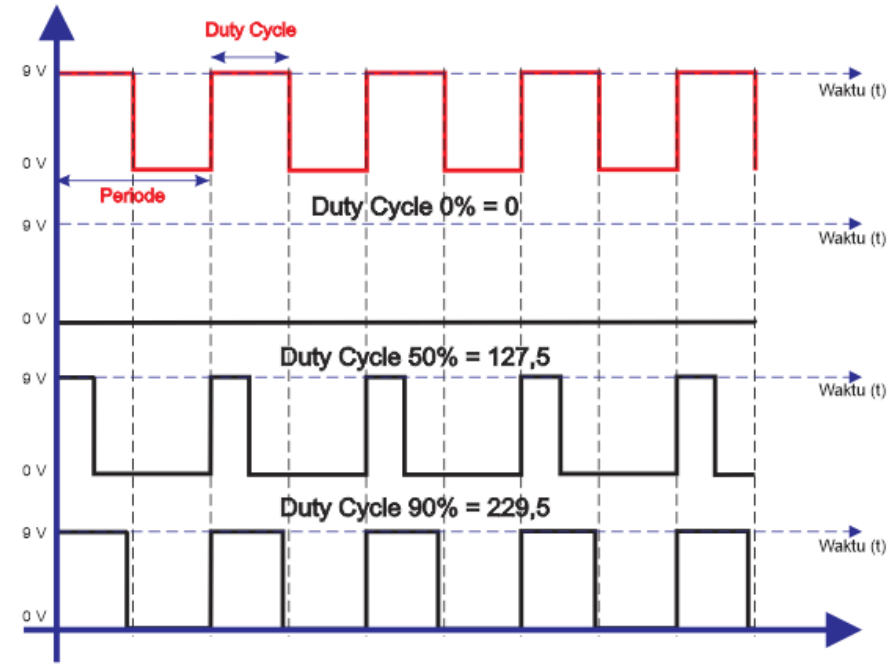

Gambar 5. Representasi Sinyal PWM untuk Sistem Scroll Saw 


\section{FLOWCHART SISTEM}

Flowchart sistem menggambarkan secara struktural cara kerja dari sistem gergaji pola otomatis yang akan dirancang. Adapun flowchart sistem dapat dilihat pada gambar berikut;

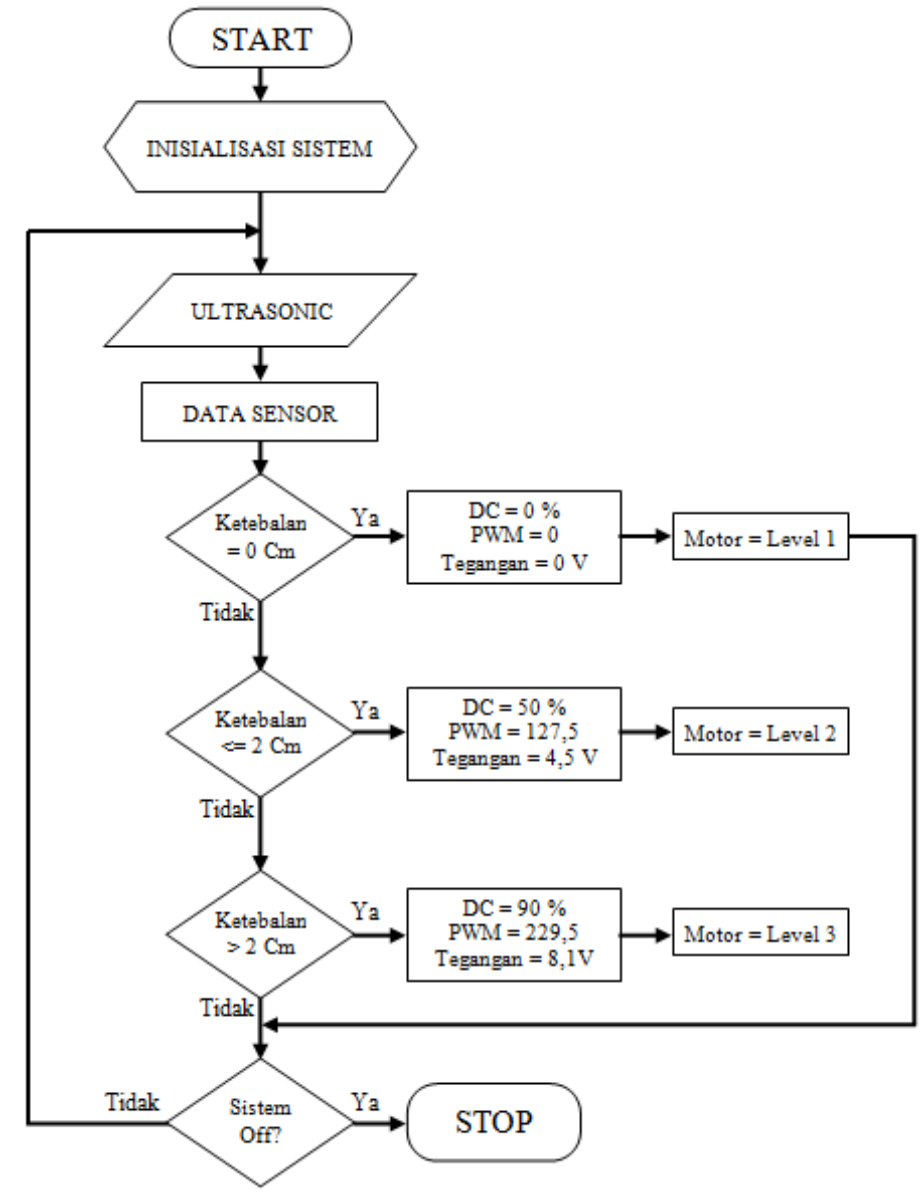

Gambar 6. Flowchart Sistem

\section{ANALISA DAN HASIL}

Proses pengujian dimulai dengan membandingkan pembacaan jarak ultrasonik dengan alas objek sebagai pembanding untuk perhitungan ketebalan objek yang akan dipotong oleh sistem gergaji pola otomatis. Untuk hasil pengujian dapat dilihat pada gambar berikut;

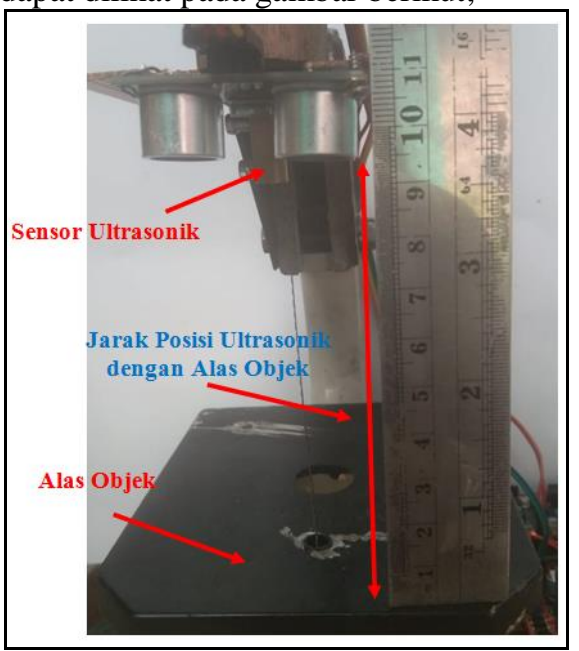

Gambar 7. Deteksi Jarak Pembacaan Ultrasonik dan Alas Objek 
Dapat dilihat pada gambar di atas, proses pengujian menggunakan sebuah penggaris sebagai pengukur jarak manual antara sensor ultrasonik dengan alas objek. Sedangkan hasil pembacaan sensor ditampilkan pada layar serial monitor pada aplikasi arduino IDE, berikut hasil pembacaan ultrasonik yang terdeteksi:

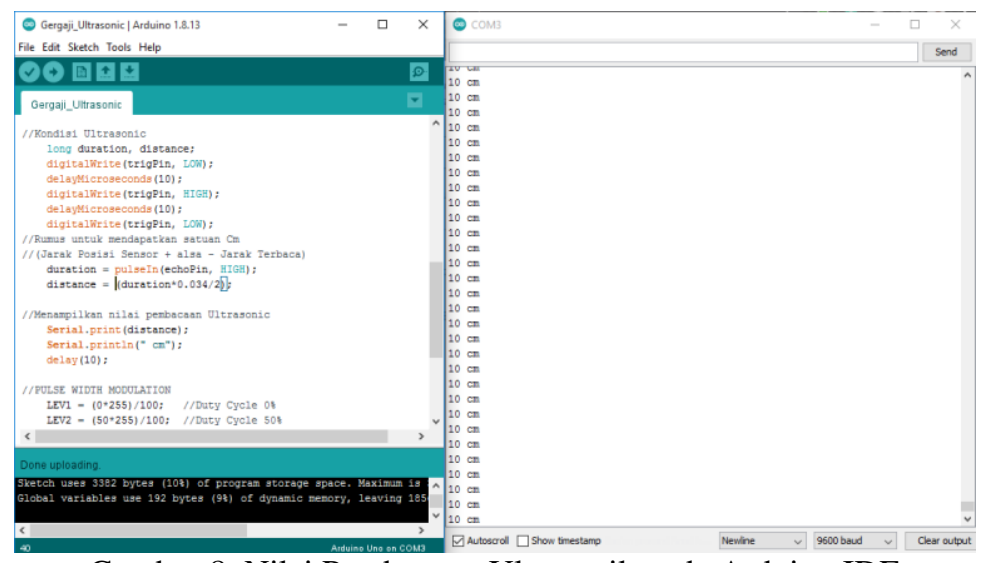

Gambar 8. Nilai Pembacaan Ultrasonik pada Arduino IDE

Berdasarkan gambar di atas dapat dilihat bahwa hasil pembacaan ultrasonik akurat dengan ukuran yang terdeteksi adalah $10 \mathrm{~cm}$.

Setelah menguji sistem gergaji pola otomatis tanpa adanya objek, proses selanjutnya adalah melakukan pengujian dengan memperhatikan ketebalan objek. Pada pengujian kali ini algoritma sudah diimplementasikan termasuk rumus pembacaan ketebalan objek, yakni Jarak Tanpa objek dikurang jarak terdeteksi. Yang artinya dalam pengujian kali ini nilai yang akan ditampilkan oleh serial monitor bukanlah jarak sensor dengan objek melainkan ketebalan objek (jarak alas objek dengan bagian atas objek). Selain itu kecepatan motor juga sudah diatur berdasarkan level kecepatan Pulse Width Modulation (PWM) yang telah diimplementasikan. Untuk level PWM sendiri diatur berdasarkan penentuan awal dengan membagi 3 Level kecepatan motor, untuk implementasi algoritma dapat dilihat pada penggalan listing program berikut;

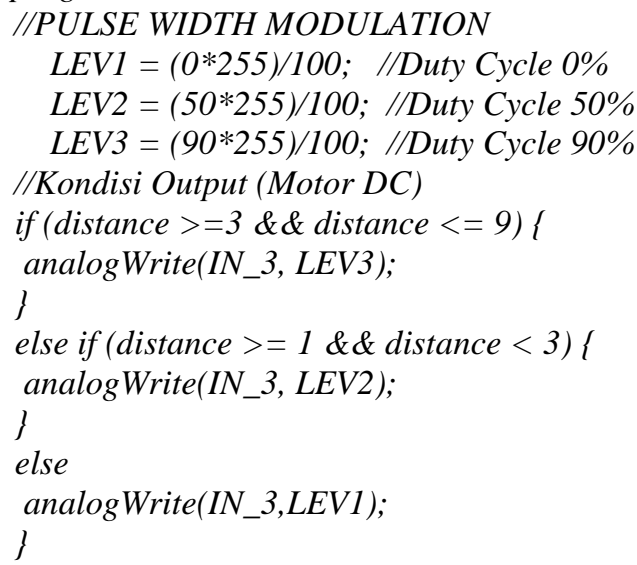

Pengujian Algoritma sistem dilakukan dengan memberikan momentum perubahan Ketebalan Objek secara simultan, dimana jarak pembacahan dirubah secara berkala dan kemudian melihat perubahan kecepatan dari pergerakan motor penggerak mata gergaji. 


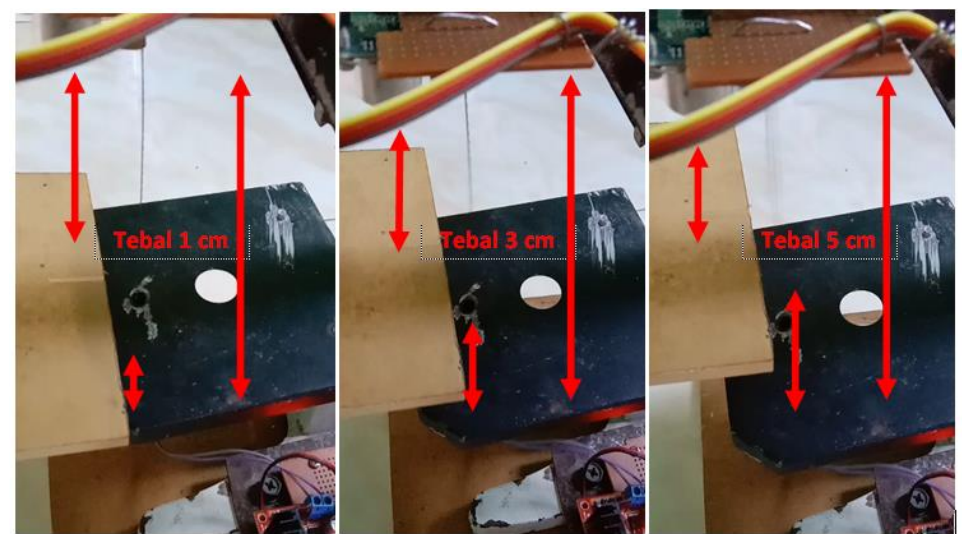

Gambar 9. Momentum Pengujian Algoritma Sistem.

Berdasarkan pengujian maka diperoleh hasil pengujian yang direpresentasikan pada tabel pengujian sebagai berikut;

\begin{tabular}{|c|c|c|c|c|c|}
\hline \multirow{2}{*}{ No. } & Keterangan & $\begin{array}{c}\text { Nilai } \\
\text { Manual }\end{array}$ & Nilai Terdeteksi Sistem & Kondisi Motor & Stasus \\
\hline \multicolumn{2}{|c|}{ Pengujian Tanpa Algoritma } & & & & \\
\hline 1 & Pengujian Jarak Alas & $10 \mathrm{Cm}$ & $10 \mathrm{Cm}$ & - & Sesuai \\
\hline \multicolumn{2}{|l|}{ Pengujian Algoritma } & & & & \\
\hline 2 & Pengujian Ketebalan 1 & $1 \mathrm{Cm}$ & $1 \mathrm{Cm}$ & OFF (Level 1) & Sesuai \\
\hline 3 & Pengujian Ketebalan 2 & $2 \mathrm{Cm}$ & $2 \mathrm{Cm}$ & ON (Level 2) & Sesuai \\
\hline 4 & Pengujian Ketebalan 3 & $5 \mathrm{Cm}$ & $5 \mathrm{Cm}$ & ON (Level 3) & Sesuai \\
\hline
\end{tabular}

\section{KESIMPULAN}

Berdasarkan hasil pengujian dan analisis maka hasil dari penelitian dapat ditarik beberapa kesimpulan antara lain sebagai berikut;

a. Teknik Kendali Pulse Width Modulation dapat diimplementasikan untuk mengendalikan kecepatan motor penggerak scroll saw berdasarkan ketebalan objek yang dipotong

b. Sistem mampu mengukur ketebalan objek menggunakan sensor ultrasonik dengan menghitung nilainilai yang bersangkutan seperti jarak sensor ultrasonik dengan alas dan dikurang dengan jarak yang terdeteksi.

c. Sistem dapat dirancang dengan menggunakan kombinasi komponen kendali arduino sebagai pemroses, ultrasonik sebagai pendeteksi objek serta motor DC sebagai penggerak mata gergaji Scroll Saw.

\section{REFERENSI}

[1] M. A. Subijantoro, "Defenisi Mesin Gergaji," 2015. .

[2] S. Arifin and A. Fathoni, "PEMANFAATAN PULSE WIDTH MODULATION UNTUK MENGONTROL MOTOR ( STUDI KASUS ROBOT OTOMATIS DUA DEVIANA ) Sekolah Tinggi Manajemen Informatika dan Komputer ASIA Malang," vol. 8, no. 2, 2014.

[3] A. Pranata and B. Anwar, "Implemantasi Fuzzy Logic Pada Sistem Monitoring Penggunaan Komputer Untuk Kesehatan Mata Berbasis,” vol. 17, no. 2, pp. 211-213, 2018.

[4] S. Y. Riska, S. I. Putri, and W. A. Rahayu, "Pelatihan Alat Pemotong Bambu Otomatis Berbasis Mikrokontroler Menuju Kampung Produktif di Desa Ngajum Gunung Kawi Malang,” vol. 11, no. 2, pp. 154-162, 2017.

[5] J. P. Soedarto, J. P. Soedarto, and J. P. Soedarto, "PENGGUNAAN MESIN GERGAJI PITA DAN MESIN AMPELAS DI UKM REPLIKA MOBIL BOYOLALI Jurusan Teknik Mesin Politeknik Negeri Semarang Jurusan Teknik Mesin Politeknik Negeri Semarang Jurusan Akuntansi Politeknik Negeri Semarang Abstrak Sumber : Kegiatan Pengabdian,” vol. 3, no. 2, pp. 18-25, 2018.

[6] P. S. F. Yudha and R. A. Sani, "IMPLEMENTASI SENSOR ULTRASONIK HC-SR04 
SEBAGAI SENSOR PARKIR MOBIL BERBASIS ARDUINO,”Einstein, vol. 5, no. 3, 2017.

[7] Z. Azmi and J. Tumangger, "IMPLEMENTASI PULSE WIDTH MODULATION UNTUK SISTEM PEMBUAT MIE," vol. 2, no. 1, pp. 20-24, 2018.

[8] Y. Mochtiarsa and B. Supriadi, "Rancangan Kendali Lampu Menggunakan Mikrokontroller ATMega328 Berbasis Sensor Getar," vol. 1, no. 1, pp. 40-44, 2016.

[9] Z. Budiarso, "Implementasi Sensor Ultrasonik Untuk Mengukur Panjang Gelombang Suara Berbasis Mikrokontroler," vol. 20, no. 2, pp. 171-177, 2015.

[10] B. Arasada and B. Suprianto, "Aplikasi Sensor Ultrasonik Untuk Deteksi Posisi Jarak Pada Ruang Menggunakan Arduino Uno Aplikasi Sensor Ultrasonik Untuk Deteksi Posisi Jarak Pada Ruang Menggunakan Arduino Uno Bakhtiyar Arasada Bambang Suprianto," Tek. Elektro, vol. 06, no. 02, pp. 1-8, 2017. 